\title{
Hippomane mancinella, Manchineel ${ }^{1}$
}

\author{
Michael G. Andreu and Melissa H. Friedman²
}

\section{Warning: all parts of manchineel are extremely poisonous. The content in this document is strictly informational. Interaction with and ingestion of any part of this tree may be lethal.}

\section{Family}

Euphorbiaceae, spurge family

\section{Genus}

Hippomane comes from two Greek words, hippo meaning "horse," and mane, which is derived from mania and means "madness." Theophrastus, an ancient Greek philosopher, gave the name Hippomane to a native plant in Greece after determining that horses became "crazy" after eating it. Linnaeus, the father of taxonomy, in turn gave the same name to this noxious tree from the Americas.

\section{Species}

The origin of the species name mancinella cannot be determined.

\section{Common Name}

\section{Manchineel}

The name "manchineel" from the Spanish "manzanilla," which means "little apple" in reference to the leaves and fruit of the apple tree (Malus spp.). However, due to its extremely toxic nature, the Spanish have also dubbed this tree "arbol de la muerte" meaning "tree of death" in reference to what happens to people if they eat the fruit.

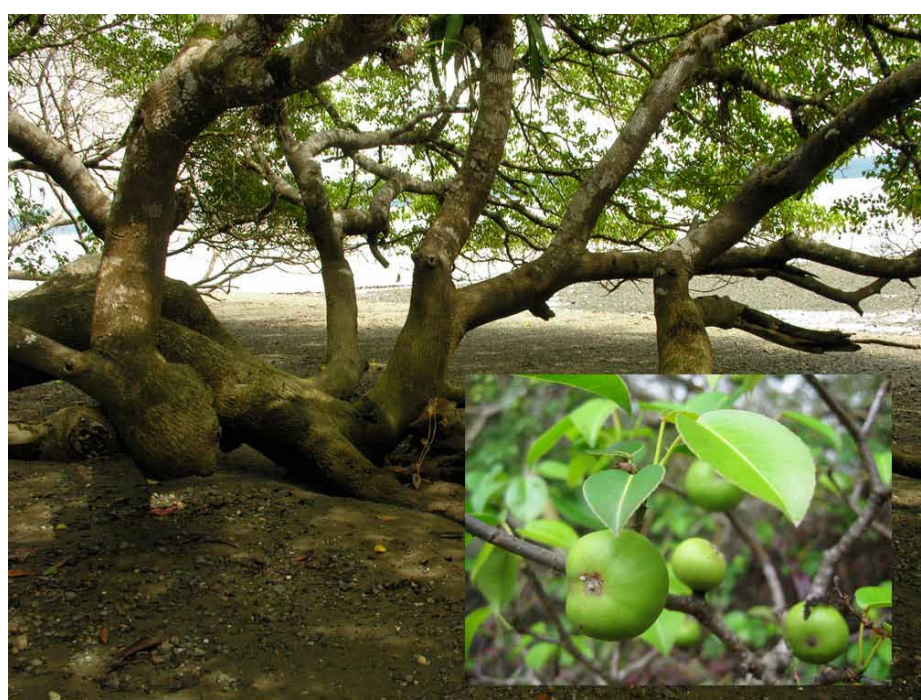

Figure 1. All portions of the manchineel tree are poisonous. Credits: Wide-angle view of Hippomane mancinella by Reinaldo Aguilar. Inset image showing detail of manchineel fruit and foliage by Eric Schmuttenmaer. CC BY-NC-SA 2.0.

\section{Description}

This poisonous tree is native to southern Florida, the Keys, many of the Caribbean islands, Mexico, and Central America. It typically occurs along the seacoasts and in brackish swamps where it grows among mangroves. Manchineel is usually a tall shrub, but it can reach heights of up to 50 feet. The leaves are simple, alternate, very finely serrated or toothed, and 2-4 inches long. Each leaf has a small gland where the leaf joins the stem. The bark is reddish-to-grayish brown and deeply furrowed or cracked looking. Flowers are yellow green and inconspicuous, but the spikes or leafless stems that the flowers emerge from are

1. This document is FOR302, one of a series of the School of Forest Resources and Conservation, Florida Cooperative Extension Service, Institute of Food and Agricultural Sciences, University of Florida. Original publication date July 2012. Visit the EDIS website at http://edis.ifas.ufl.edu.

2. Michael G. Andreu, associate professor; Melissa H. Friedman, research scientist; School of Forest Resources and Conservation, University of Florida, Gainesville, Florida 32611. 
visible. The fruit is a bright-green pome that looks distinctly like an apple; however, it is only 1-2 inches in diameter and turns greenish yellow when ripe.

\section{Allergen}

Warning: all parts of manchineel are extremely poisonous and interaction with or ingestion of any part of this tree may be lethal. This tree produces a thick, milky sap that can ooze out of the leaves, twigs, bark, and fruit. The sap has been known to cause burn-like blisters when it comes in contact with the skin. People have reported heavy inflammation of the eyes and even temporary blindness from irritants carried in the smoke of this tree's burning wood. While some claim that they are immune to the noxious sap when it interacts with their skin, ingesting any part of this tree can be lethal and is not recommended.

\section{Applications}

\section{Commercial/Practical}

Manchineel has been used to make furniture since colonial times, with the poisonous sap thought to become neutralized by drying the wood in the sun. However, those working with the fresh-cut wood must be careful, since interacting with the poisonous sap can be a strong irritant to any part of the body.

\section{Cultural}

Native peoples used the poisonous sap to coat their arrows when hunting. In Florida, manchineel is in danger of becoming extinct and is a state-listed endangered species.

\section{Medicinal}

It has been documented that gum from the bark of this tree has been used to treat venereal disease and dropsy in Jamaica, while dried fruits have been used as a diuretic.

\section{Wildlife}

Though the manchineel tree is poisonous to humans and many animals, the "garrobo" or "iguana" of Central and South America is able to eat the fruits of this tree, and is sometimes found living among the tree's limbs.

\section{Additional References}

The Institute for Regional Conservation (2012). The Floristic Inventory of South Florida Database Online. Retrieved from http://regionalconservation.org/ircs/database/plants/ PlantPage.asp?TXCODE=Hippmanc.

USDA Natural Resources Conservation Service (n.d.). Plants Database. Retrieved from http://plants.usda.gov/ java/nameSearch?keywordquery=hIPPOmane + mancinella \&mode $=$ sciname\&submit. $x=0$ \&submit. $y=0$.

Wunderlin, R. P., \& Hansen, B. F. (2008). Atlas of Florida Vascular Plants. Retrieved from http://florida.plantatlas.usf. edu/Plant.aspx?id=2806. 